\title{
Japanese plan to join the big space league by 2001
}

\section{Tokyo}

PLANS to put Japan alongside other nations with a major investment in space were heralded by an ambitious 15-year development programme approved by the Space Activities Commission last week. The programme should turn Japan into a major space nation by the end of the century and enable it to compete with the European Ariane and the US space shuttle for the launch of large communications satellites early in the next decade.

At the heart of the programme is the decision to develop a new rocket - the $\mathrm{H} 2$ - powered by a domestically developed cryogenic oxygen-hydrogen engine, capable of putting a $2,000-\mathrm{kg}$ satellite into geosynchronous orbit. Development costs are estimated at 200,000 million yen $(\$ 870$ million) and will necessitate big increases in the National Space Development Agency (NASDA)'s annual budget of Y130,000 million.

In addition, the programme calls for participation in building the US space station - although to what extent is not yet clear. Earlier Japanese plans for a manned space flight are discarded as uneconomic but provision is made for continuing use of the space shuttle for development of new materials under zero-gravity conditions. The new programme - the first to be announced for six years - was given the goahead at a meeting of the Space Activities Commission chaired by Michiyuki Isurugi, director general of the Science and Technology Agency, which is responsible for all of Japan's "'big science".

The decision to build the $\mathrm{H} 2$ rocket stems from confidence that Japan has mastered much of what it can learn from the United States in the field of launcher development. After a late entry into the space race in 1969 , NASDA rapidly acquired the capability to launch small satellites by the aggressive import of US rocket technology. Its first launch vehicle, the three-stage N1, was essentially a copy of the Thor-Delta and could lift only a $130-\mathrm{kg}$ payload into geosynchronous orbit. The N2, which replaced it in 1981, brought payload capacity up to a modest $350 \mathrm{~kg}$. But while the $\mathrm{N}$ series rockets were being built under US licence, the Japanese were developing the $\mathrm{H1}$, a far more powerful cryogenic oxygen-hydrogen engine that would mix Japanese and US technology and be capable of taking a $550-\mathrm{kg}$ payload into orbit by the mid-1980s. Next in line would have been an extended version, the $\mathrm{H} 1 \mathrm{~B}$, designed to take an $800 \mathrm{-kg}$ payload. But rapid development of the cryogenic engine has allowed the bold decision to skip the $\mathrm{H} 1 \mathrm{~B}$ in favour of the new $\mathrm{H} 2$, to be ready soon after 1990 .

Success will give Japan the capacity to launch 2,000-kg satellites - the same capacity as the Ariane 4 rocket planned for completion around the same time and only a little less than the 2,270-kg capacity of the

\section{Japan versus Europe}

JUST before Japan announced it would develop a big cryogenic launcher (H2 - see above), a senior French rocket engineer discussed the plan with the Japanese space agency, NASDA. The engineer, M. Jacques Borromee, is in charge of developing the cryogenic engine for the European Ariane 4 launcher - with which Japan believes $\mathrm{H} 2$ is in direct competition.

French reports described the meetings as "fruitful", but according to a spokesman for the French space agency CNES, the object of the visit was merely "information". The meeting was to be seen in the context of many meetings between CNES and other space agencies, he said, and nothing was said about possible cummercial collaboration between CNES and NASDA.

However another French space engineer described the potential $\mathrm{H} 2$ payload of $2,000 \mathrm{~kg}$ in geostationary orbit as modest. Ariane 1 can achieve $1,825 \mathrm{~kg}$, and Ariane 3 (to be first launched this summer) $2,580 \mathrm{~kg}$. Ariane 4 with its cryogenic engines and four liquid boosters could put up a

\section{size the key}

4,200-kg communications satellite, the size adopted by the Intelsat corporation (a 108-nation body which effectively sets world standards for such satellites) for its next (Intelsat VI) series. Also, the first Ariane 4 proving flight is planned for 14 March 1986, four years ahead of any likely launch of the Japanese H2. This flight of Ariane 4 will be in the "most difficult" configuration, using two liquid fuel and two solid fuel boosters, with a potential $3,700-\mathrm{kg}$ payload. If successful it will prove the full capability of Ariane 4.

The question becomes one of the weight of communications satellites by the end of the decade. In Japan there is a view that it will fall to around $2,000 \mathrm{~kg}$, in part because of Japanese efforts to microminiaturize satellites. If successful, Ariane 4's maximum payload may become unnecessary but already it is planned to have members of the Ariane 4 family suited to a smaller payload by variations in the number and type of boosters carried by the first stage.
Illmensee inquiry CORRECTION

IN the article under this heading on page 673 of last week's Nature (23 February), a word was inadvertently omitted from the second sentence. It should have read: 'But in a report that is highly critical of Illmensee's experimental records, the six members of the commission are unable to reach agreement on whether "the hypothesis that the protocols were fabricated could be upheld"; some felt it could not, others considered "there was no compelling evidence to support or refute the hypothesis",. The word "not" was omitted due to an error in the editorial process. We apologize for the error and any distress it may have caused.

space shuttle. And by using domestic technology, Japan will be free from legal restrictions on competing with the United States that come with building under US licence.

The entry of Japan into the large satellite launching business is bound to make both Europe and the United States nervous. There is also nervousness within Japan that the project is too great a gamble and that there will be insufficient business for all three launcher groups. At present, only large communications satellites reach the $2,000-\mathrm{kg}$ mark and critics of the programme feel Japan would be safer sticking to the medium-sized satellite market. But the Japanese Government has already been irritated by US attempts to limit the transfer of satellite technology to Japan and independence from the United States is an important goal.

While the start of the $\mathrm{H} 2$ project now seems certain, the extent of Japanese participation in the US space station project is less clear. Hard bargaining is likely when James Beggs, administrator of the US NationaL Aeronautics and Space Administration (NASA), arrives in Japan on 11 March to discuss the project. The Americans have reportedly asked Japan to take a 10 per cent share in the space station's development costs. Although the Japanese response has so far been encouraging, it seems unlikely with the present budget deficit that the Diet will approve expenditure on this scale - or that the Science and Technology Agency will tolerate the cuts in other projects that would probably become necessary.

The Japanese Government will also find itself in a serious dilemma if the US Government cannot guarantee that the space station will be used only for peaceful purposes. The Japanese constitution specifically forbids national military forces and the Japanese public is remarkably sensitive to any increase in military involvement with the United States. Some difficult negotiations over how much say the Japanese have in the deployment of the station are almost certain to lie ahead. 